\title{
Lactobacillus plantarum PADA FESES INDIVIDU DEWASA SEHAT YANG MENGONSUMSI Lactobacillus plantarum IS-10506 DARI DADIH
}

\author{
[Lactobacillus plantarum in Stool of Apparently Healthy Adults Consuming \\ Lactobacillus plantarum IS-10506 from Dadih]
}

\author{
Azmier Adib ${ }^{1 *}$, Mardiastuti H. Wahid11), Pratiwi Sudarmono1) dan Ingrid S. Surono2) \\ 1) Departemen Mikrobiologi, Fakultas Kedokteran, Universitas Indonesia, Jakarta \\ 2) Food Technology Study Program, Faculty of Engineering, Bina Nusantara University / SEAMEO RECFON,
} Universitas Indonesia, Jakarta

Diterima 08 Mei 2013 / Disetujui 19 November 2013

\begin{abstract}
A placebo double blind pre-post human study was conducted in apparently healthy adults. There were two treatment groups consisting of Group $A$ and $B$ representing probiotic and placebo group, respectively. Twenty four participants were randomly assigned, each supplemented with either placebo or probiotic Lactobacillus plantarum IS-10506. The micro encapsulated powder was given at a dose of $2.6 \times 10^{10} \mathrm{CFU} / \mathrm{day}$ for 21 consecutive days. Stool samples were collected before and after the supplementation. The fresh stool samples were analyzed for the viability of Lactobacillus sp. by conventional plate count method in MRS agar. Some stool samples were kept frozen to be analyzed by using real time PCR to trace back the availability of Lactobacillus plantarum with species specific primer. The Lactobacillus $s p$. in stools of healthy adults given microencapsulated probiotic Lactobacillus plantarum IS-10506 powder was significantly more than those who consumed microencapsulated placebo powder. Molecular detection by qPCR confirmed the availability of Lactobacillus plantarum in fecal samples of the probiotic group after given the supplementation for 21 days. The molecular detection validation confirmed that probiotic Lactobacillus plantarum was available in the fecal samples of the probiotic group of healthy adults. However, the availability and viability of Lactobacillus plantarum were not consistently found in the intestinal tract.
\end{abstract}

Keywords: availability, Lactobacillus plantarum IS-10506, probiotic, qPCR, viability

\begin{abstract}
ABSTRAK
Penelitian ini menggunakan placebo double blind pre-post treatment design, yang dilakukan pada subjek individu dewasa sehat. Terdapat 2 kelompok perlakuan yang terdiri atas kelompok A dan B, yaitu kelompok perlakuan yang diberikan probiotik Lactobacillus plantarum IS-10506 dan kontrol (plasebo). Dua puluh empat orang telah dipilih secara acak, masing-masing diberi plasebo atau probiotik Lactobacillus plantarum IS-10506. Bubuk kering dalam wadah kapsul diberikan sebagai suplemen dengan dosis 2.6x1010 CFU/hari selama 21 hari berturut-turut. Sampel feses diambil sebelum dan sesudah suplemen diberikan. Sampel feses segar dikultur pada media MRS dan dilakukan hitung jumlah bakteri secara konvensional (plate count) untuk mengetahui viabilitas Lactobacillus sp. Sebagian sampel dibekukan untuk pemeriksaan real time PCR untuk melihat keberadaan Lactobacillus plantarum IS-10506 dengan primer spesifik. Keberadaan Lactobacillus sp pada feses orang dewasa sehat yang diberi kapsul berisi probiotik Lactobacillus plantarum IS-10506 lebih banyak secara signifikan dibandingkan individu yang diberi bubuk plasebo. Deteksi molekuler mengkonfirmasi dan memvalidasi bahwa Lactobacillus plantarum IS-10506 berada dalam feses kelompok probiotik setelah pemberian suplemen selama 21 hari. Namun, keberadaan dan viabilitas Lactobacillus plantarum IS-10506 tidak ditemukan secara konsisten dalam saluran cerna.
\end{abstract}

Kata kunci: availabilitas, Lactobacillus plantarum IS-10506, probiotik, real time PCR, viabilitas

\section{PENDAHULUAN}

Seiring semakin meningkatnya kesadaran manusia akan pentingnya hidup sehat maka meningkat pula penelitian dan pemasaran produk makanan yang berpotensi pemeliharaan kesehatan tubuh. Produk makanan yang bermanfaat bagi kesehatan dikenal sebagai makanan fungsional. Salah satu makanan fungsional adalah makanan yang mengandung probiotik, yaitu mikroba hidup yang bila dikonsumsi dapat

*Penulis Korespondensi:

Email: gue_gondronk@yahoo.com; Telp.: 082123289522 menimbulkan efek terapeutik pada tubuh dengan cara memperbaiki keseimbangan mikroflora dalam saluran pencernaan. Berbagai macam produk susu fermentasi telah diklaim sebagai produk probiotik. Adapun definisi probiotik menurut FAO dan WHO, yaitu mikroba hidup yang berpengaruh positif bagi kesehatan ketika dikonsumsi dalam jumlah tertentu (Weichselbaum, 2009).

Mikroba yang berperan sebagai probiotik di antaranya bakteri asam laktat (BAL), yang seringkali digunakan dalam fermentasi makanan atau minuman. Bakteri probiotik yang umumnya ditambahkan dalam produk fermentasi susu adalah Lactobacillus dan Bifidobacteria (de Vrese M et al. 2011). 
Bakteri asam laktat memiliki kemampuan untuk bertahan hidup dan membentuk koloni dalam usus, kemudian memproduksi asam laktat dan senyawa metabolit lainnya, serta menstimulasi respon kekebalan tubuh (Wells, 2011). Beberapa strain probiotik berperan menjaga keseimbangan mikrobiota usus, dan membantu meningkatkan sistem kekebalan tubuh. Strain probiotik komersial yang berasal dari negara maju belum tentu cocok dan optimal fungsinya bagi orang Indonesia. Di Indonesia dikenal beberapa makanan tradisional, salah satu yang berpotensi sebagai makanan fungsional adalah "dadih", yaitu hasil fermentasi susu kerbau yang diolah secara tradisional di Sumatra Barat, atau produk semacam yogurt (Surono, 2009).

Hasil analisis mikrobiologis beberapa jenis BAL yang terkandung di dalam dadih meliputi Lactobacillus plantarum, Streptococcus thermophillus, Leuconostoc, Lactococcus lactis subsp. cremoris (Surono, 2003). Bagi penderita "lactose intolerance", mengonsumsi dadih merupakan salah satu alternatif untuk memperoleh manfaat dari susu. Adanya kandungan BAL seperti Lactobacillus, Streptococcus, Leuconostoc dan Lactococcus membuat dadih memiliki khasiat kesehatan antara lain menyeimbangkan mikroba dalam saluran usus, menghambat pertumbuhan bakteri patogen yang menyebabkan diare, menurunkan terjadinya mutasi sel, menurunkan kadar kolesterol darah dan meningkatkan sistem kekebalan tubuh.

Sebagai probiotik indigenous asal Indonesia, dadih terbukti tahan terhadap kondisi ekstrim asam dan garam empedu dan berpotensi sebagai probiotik yang tepat untuk orang Indonesia, sebab sudah sering terpapar bakteri kontaminan maupun patogen yang ada di Indonesia (Collado et al. 2007b). Kandungan gizi dan manfaat kesehatan yang dimiliki dadih menjadikannya sebagai produk pangan yang potensial untuk dikembangkan sebagai industri pangan. Lactobacillus plantarum IS-10506, memperlihatkan kemampuan untuk melekat yang tinggi pada senyawa hidrokarbon, dan memiliki kemampuan berautoagregasi, artinya L. plantarum IS-10506 asal dadih tersebut mempunyai kemampuan beradesi atau menempel pada sel epitel saluran cerna dengan baik (Collado et al. 2007a). Menurut Collado et al. (2007a) dinding sel bakteri asam laktat diketahui dapat mengikat senyawa mutagen dan karsinogen pemicu kanker dan membran selnya dapat menyerap kolesterol. Penggunaan Lactobacillus plantarum untuk pengobatan irritable bowel syndrome telah teruji, terdapat bukti bahwa mikroba ini mengurangi rasa sakit, mencegah konstipasi dan kembung (Bixquert, 2009). Nissen et al. (2009), memperlihatkan secara in vitro bahwa $L$. plantarum dapat memperkuat integritas usus, serta aktivitas metabolik sel usus dan menstimulasi respon imun.

Salah satu persyaratan bakteri asam laktat yang dapat digunakan sebagai agensia probiotik adalah kemampuannya untuk tumbuh dan berkembang dalam saluran pencernaan, sehingga dapat menjalankan peranannya menjaga keseimbangan flora usus dan meningkatkan kesehatan tubuh. Seperti telah diketahui tentang pentingnya viabilitas probiotik, yaitu jumlah mikroba hidup harus cukup untuk memberikan efek positif bagi kesehatan dan mampu berkolonisasi sehingga dapat mencapai jumlah yang diperlukan. Viabilitas sel mikroba dalam produk probiotik harus mencapai $10^{7}-10^{9} \mathrm{CFU} / \mathrm{g}$, karena viabilitas probiotik akan mengalami penurunan selama penyimpanan dan saat berada dalam sistem pencernaan. Hal ini disebabkan karena faktor lingkungan yang tidak menguntungkan bagi kelangsungan hidup bakteri probiotik, diantaranya adalah $\mathrm{pH}$ rendah dan garam empedu dalam sistem pencernaan.

Mengingat Lactobacillus plantarum IS-10506 berasal dari makanan indigenous Indonesia (dadih) dan mampu melekat pada saluran cerna, memungkinkan bakteri ini dimanfaatkan sebagai probiotik lokal. Oleh karena itu, dibutuhkan penelitian tentang keberadaan dan peningkatan jumlah Lactobacillus plantarum IS-10506 pada saluran cerna yang menunjukkan adanya pertumbuhan, sebagai salah satu persyaratan pemanfaatan bakteri ini sebagai probiotik (Surono, 2003; Collado et al. 2007a).

\section{BAHAN DAN METODE}

\section{Bahan}

Bahan utama yang digunakan dalam penelitian ini adalah bakteri probiotik Lactobacillus plantarum IS-10506 asal dadih. Real time PCR/qPCR (mesin PCR system BioRad), High Pure PCR Template Preparation Kit (Roche $\left.{ }^{\circledR}\right)$, FastStart SYBR Green Master, primer plan F (5' - CCG TTT ATG CGG AAC ACC TA 3' Forward) dan pREV (5' - TCGGGA TTA CCA AAC ATC AC 3' Reverse).

\section{Preparasi sampel}

Setelah memperoleh izin kelayakan riset (etical clearance) dari Komite Etik Penelitian FKUI, dan mendapatkan persetujuan subjek (Informed of Consent atau IOC) yang memenuhi kriteria inklusi dilakukan seleksi secara consecutive sampling terhadap subjek orang dewasa sehat di komunitas dengan menggunakan formulir skrining.

Cara pengambilan sampel feses subjek adalah sebagai berikut: toilet disiram dengan karbol terlebih dahulu dan feses tidak boleh terkena/terendam dalam air di toilet selanjutnya $\pm 2 \mathrm{~g}$ feses dimasukkan ke dalam pot feses bersendok untuk dianalisis kandungan bakteri asam laktat dalam feses segar dalam waktu 1-2 jam. Selama penelitian berlangsung subjek tidak diperbolehkan mengonsumsi antibiotik selama 21 hari. Feses dimasukkan ke dalam pot feses yang dimasukkan ke dalam kotak pendingin beserta dry ice untuk menyimpan sampel kemudian dikirim ke Laboratorium Mikrobiologi Klinik untuk dilakukan kultur dan pemeriksaan real time PCR.

Sampel feses dibagi menjadi 2 secara asepsis, yaitu $1 \mathrm{gram}$ untuk kultur media sebagai screening Lactobacillus sp dan 200 mg untuk pemeriksaan qPCR. Sampel untuk pemeriksaan qPCR dimasukkan ke dalam tabung eppendorf dan disimpan pada suhu $-80^{\circ} \mathrm{C}$ sampai dilakukan analisis. Sampel untuk kultur media ditimbang hingga didapat 1 gram feses dan ditambahkan dengan $9 \mathrm{~mL}$ PBS. Selanjutnya sampel divorteks sampai homogen dan diencerkan dari pengenceran $10^{-1}$ hingga 10-10 


\section{Uji saring Lactobacillus sp dengan media MRS}

Media pembiakan sebagai screening Lactobacillus sp yang digunakan adalah MRS (deMan Rogosa Sharpe) untuk menghitung viabilitas Lactobacillus sp dalam feses. Sejumlah $1 \mathrm{gram}$ sampel feses diencerkan secara berseri. Pengencer yang digunakan adalah fosfat buffer atau PBS 1x. Sampel berupa feses dimasukkan ke dalam tabung screw cap berisi PBS $1 \mathrm{x}$ dengan pengenceran berseri dari $10^{-1}$ sampai dengan 10-10. Dari pengenceran $10^{-5}$ sampai dengan $10^{-8}$ diambil masingmasing $1 \mathrm{~mL}$ untuk dilakukan pour plate technique pada MRS agar yang diberi indikator Brom Cresol Purple. Kemudian diinkubasi pada suhu $37^{\circ} \mathrm{C}$ selama dua hari (Bujalance et al. 2006). Setelah 48 jam akan terlihat koloni bewarna kuning, kemudian dilakukan pemeriksaan mikroskopik untuk pewarnaan Gram dan uji katalase.

\section{Identifikasi bakteri asam laktat}

Identifikasi dilakukan dengan pewarnaan Gram dan uj katalase. Beberapa mikroorganisme memiliki enzim katalase yang dapat memecah hidrogen peroksida $\left(\mathrm{H}_{2} \mathrm{O}_{2}\right)$ menjadi oksigen dan air. Ketika koloni diberikan $\mathrm{H}_{2} \mathrm{O}_{2}$, akan timbul gelembung atau bubble maka disebut katalase positif dan sebaliknya.

\section{Isolasi DNA}

Isolasi DNA pada penelitian ini menggunakan High Pure PCR Template Preparation Kit (Roche $\left.{ }^{\circledR}\right)$. Sebanyak 500-1000 $\mu \mathrm{L}$ PBS ditambahkan ke tabung eppendorf yang berisi sampel tinja beku, kemudian divorteks selama 30 detik sampai 1 menit hingga homogen. Sampel sebanyak $200 \mu \mathrm{L}$ dimasukkan ke dalam tabung eppendorf steril baru yang telah dilabel, kemudian ditambahkan $200 \mu \mathrm{L}$ binding buffer dan $40 \mu \mathrm{L}$ Proteinase $\mathrm{K}$ Larutan dicampur secepatnya dan diinkubasi pada suhu $72^{\circ} \mathrm{C}$ selama 15 menit. Setelah inkubasi, $100 \mu \mathrm{L}$ isopropanol ditambahkan, dilarutkan dan dimasukkan ke dalam High pure filter tube, kemudian disentrifus $8000 \times$ g selama 1 menit. Collection tube dibuang beserta larutannya, diganti dengan yang baru dan ditambahkan $500 \mu \mathrm{L}$ Inhibitor Removal Buffer disentrifus $8000 \times$ g selama 1 menit. Collection tube dibuang beserta larutannya, diganti dengan yang baru dan ditambahkan $500 \mu \mathrm{L}$ wash buffer, lalu disentrifus $8000 \mathrm{x}$ g selama 1 menit. Collection tube dibuang beserta larutannya, diganti dengan yang baru dan ditambahkan $500 \mu \mathrm{L}$ wash buffer. Selanjutnya high pure filter tube disentrifus $13000 \times$ g selama 10 detik; collection tube dibuang. High pure filter tube dimasukkan kedalam tabung eppendorf steril dan ditambahkan $200 \mu \mathrm{L}$ elution buffer, disentrifus $8000 \mathrm{x}$ g selama 1 menit; high pure filter tube dibuang. Tabung eppendorf berisi DNA disimpan ke dalam pendingin dengan suhu di bawah $20^{\circ} \mathrm{C}$.

\section{Optimasi}

Pada penelitian ini dilakukan optimasi berbagai kondisi reaksi termasuk optimasi suhu annealing primer, spesifisitas primer. Kedua pasang primer planF (5' - CCG TTT ATG CGG AAC ACC TA - 3' Forward) dan pREV (5' - TCGGGA TTA CCA AAC ATC AC - 3' Reverse) digunakan untuk deteksi DNA $L$. plantarum. Optimasi suhu annealing untuk DNA $L$. plantarum menggunakan mesin PCR system Biorad, pada suhu 62; 61.5;
$60.3 ; 58.4 ; 55.9 ; 54.1 ; 52.8$ dan $52^{\circ} \mathrm{C}$. Penentuan suhu gradien berdasarkan perhitungan masing-masing $\mathrm{Tm}$ (melting temperature) primer yaitu berkisar $60^{\circ} \mathrm{C}$.

Hal yang pertama kali dilakukan adalah membuat master mix PCR kemudian dilakukan penambahan cetakan DNA dan terakhir penambahan kontrol positif DNA L. plantarum (Torriani et al. 2001), Real time PCR pada penelitian ini dilakukan dengan membuat campuran utama PCR (master mix solution). Master mix solution dipersiapkan, terdiri dari larutan Fast Start SYBR Green Master sebanyak $12.5 \mu \mathrm{L}$, Water PCR Grade sebanyak $7.192 \mu \mathrm{L}$, Primer plan F sebanyak $0.1 \mu \mathrm{L}$, Primer pREV sebanyak $0.208 \mu \mathrm{L}$. Volume master mix untuk satu kali reaksi adalah $20 \mu \mathrm{L}$. Campuran tersebut dicampur sampai homogen dan dibagi ke dalam tabung PCR dalam jumlah yang tepat. Cetakan (DNA) yang telah diisolasi dari sampel dimasukkan ke dalam campuran sebanyak $5 \mu \mathrm{L}$. Tabung PCR yang berisi PCR mix dan cetakan kemudian dimasukkan kedalam mesin PCR system Biorad dengan siklus sebagai berikut initial PCR activation selama 10 menit pada suhu $95^{\circ} \mathrm{C}$; denaturasi pada suhu $95^{\circ} \mathrm{C}$ selama 15 detik; annealing atau penempelan primer pada suhu $58.5^{\circ} \mathrm{C}$ selama 30 detik; extensión atau pemanjangan selama 30 detik pada suhu $72^{\circ} \mathrm{C}$ dengan jumlah siklus 40 siklus.

\section{Batas deteksi}

Batas deteksi L. plantarum dilakukan berdasarkan pengenceran berseri suspensi $L$. plantarum dalam PBS $1 \mathrm{x}$ dilakukan dengan pengenceran $1 / 10$ kali suspensi $L$. plantarum dari suspensi sel dari $10^{-1}$ hingga $10^{-10}$. Untuk setiap pengenceran diambil $200 \mu \mathrm{L}$ untuk kultur media dan untuk qPCR. Kultur dilakukan pada media MRS yang ditambahkan brom cresol purple kemudian diinkubasi pada suhu $37^{\circ} \mathrm{C}$ selama 14 16 jam, kemudian dilakukan hitung koloni (CFU/mL) pada pengenceran $10^{-5}$ hingga $10^{-10}$. Sementara, untuk qPCR dilakukan isolasi DNA dari masing-masing pengenceran dengan kit Roche ${ }^{\circledR}$ High Pure PCR Template Preparation Kit. Total reaksi PCR yang digunakan adalah $25 \mu \mathrm{L}$ per tabung PCR dengan volume cetakan $5 \mu \mathrm{L}$.

Optimasi dilakukan terhadap adanya inhibitor pada sampel feses dengan menggunakan cara kerja yang sama dengan batas deteksi baik untuk kultur media maupun qPCR, namun didahului dengan sentrifus sampel feses pada $14000 \times \mathrm{g}$ selama 15 menit, supernatan diambil dan dibuat suspensi dengan volume masing-masing tabung adalah $200 \mu \mathrm{L}$. Pada tabung pertama yang telah berisi supernatan feses ditambahkan kultur murni Lactobacillus plantarum.

\section{Uji spesifisitas primer}

Pada penelitian ini dilakukan uji spesifisitas primer terhadap 12 bakteri, yaitu L. plantarum, E. coli, Pseudomonas aeuroginosa, Klebsiella pneumoniae, Bifidobacteria sp, Bacillus subtilis, Proteus mirabilis, Serratia marcescens, Enterobacter aerogenes, Salmonella Typhi, Shigella sp, dan Bacteroides fragilis. Isolasi DNA dilakukan dengan High Pure PCR Template Preparation Kit (Roche $\left.{ }^{\circledR}\right)$. Total reaksi PCR yang digunakan per tabung PCR adalah $25 \mu \mathrm{L}$ dengan volume cetakan $5 \mu \mathrm{L}$. 


\section{HASIL DAN PEMBAHASAN}

\section{Karakteristik subjek dan sampel}

Karakteristik umur dari 23 subjek pada penelitian ini menunjukkan rata-rata 36.54 tahun dengan rentang 22-51 tahun dan nilai tengah (median) adalah 37 tahun. Distribusi subjek berdasarkan jenis kelamin menunjukkan 12 orang adalah berjenis kelamin wanita dan 11 orang adalah laki-laki. Sampel yang dikumpulkan selama periode Oktober 2009-Maret 2010 dinilai pemenuhan kriteria inklusinya. Selama periode tersebut diperoleh 35 sampel, yang terdiri atas 23 sampel memenuhi kriteria inklusi, sedangkan 12 sampel tidak.

\section{Keberadaan Lactobacillus sp pada media kultur}

Dari 23 sampel fases yang diperiksa per minggu, 10 sampel positif mengandung Lactobacillus sp pada medium MRS. Hasil pemeriksaan mikroskopik terhadap koloni yang tumbuh pada media MRS menunjukkan Gram positif batang dan hasil uji katalase adalah negatif. Data hasil pemeriksaan kultur pada penelitian ini menunjukkan adanya peningkatan jumlah koloni Lactobacillus sp setelah diberi perlakuan hingga minggu ke dua. Namun peningkatan tersebut secara statistik tidak nyata $(p>0.05)$.

\section{Kondisi qPCR optimum untuk pengujian $L$. plantarum}

Optimasi suhu annealing primer yang digunakan pada real time PCR dilakukan untuk mendapatkan suhu optimal agar mendapatkan hasil yang diharapkan. Optimasi yang dilakukan menggunakan DNA L. plantarum IS-10506 yang dipakai sebagai kontrol positif.

Pada penelitian ini, suhu annealing yang digunakan adalah suhu $62 ; 61.5 ; 60.3 ; 58.4 ; 55.9 ; 54.1 ; 52.8 ; 52^{\circ} \mathrm{C}$. Suhu annealing yang optimal dari pasangan primer planF dan $\mathrm{pREV}$, adalah suhu $58.4^{\circ} \mathrm{C}$ atau suhu $58.5^{\circ} \mathrm{C}$ (Gambar 1), dimana pada suhu lainnya terdapat primer dimer ketika dikonfirmasi dengan agarose di geldox (Gambar 2) dan pada melting curve terlihat perbedaan posisi peak dengan kontrol positif.

Optimasi batas deteksi dilakukan dengan menggunakan real time PCR dan kultur media L. plantarum. Batas deteksi yang dilakukan berdasarkan serial pengenceran berseri dari suspensi bakteri $L$. plantarum dalam PBS $1 \mathrm{x}$ dalam media MRS terdapat pada pengenceran $10^{-7}$ dengan jumlah koloni 4 $\mathrm{CFU} / \mathrm{mL}$, sedangkan pada qPCR pada pengenceran 10-10 DNA masih terdeteksi. Hasil tersebut membuktikan bahwa metode real time PCR lebih sensitif dalam mengidentifikasi $L$. plantarum dibandingkan dengan culture dependent.

Hasil uji simulasi dengan menggunakan supernatan feses sebagai larutan pengencer yang kemudian diberikan bakteri $L$. plantarum pada media MRS didapat hasil yang sama, yaitu bakteri tidak tumbuh pada pengenceran $10^{-8}$, namun nilai $C t$ pada qPCR lebih sensitif hingga pengenceran 10-10, DNA masih terdeteksi.

Penentuan spesifisitas kedua pasang primer (planF dan pREV) dilakukan terhadap DNA L. plantarum, Escherichia coli, Pseudomonas aeuroginosa, Klebsiella pneumonia, Bifidobacteria sp, Bacillus subtilis, Proteus mirabilis, Serratia marcescens, Enterobacter aerogenes, Salmonella Typhi,
Shigella sp, dan Bacteroides fragilis. Hasil PCR semua bakteri di atas menunjukkan hasil negatif, kecuali L. plantarum.

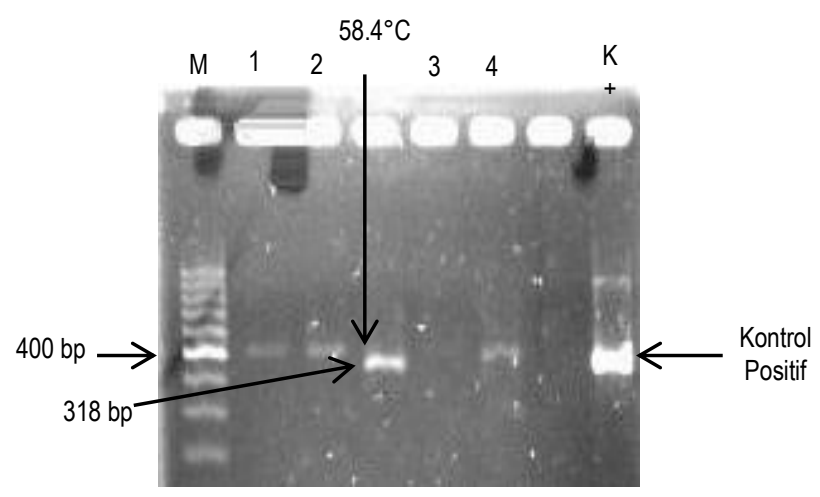

Gambar 1. Optimasi suhu annealing primer dengan menggunakan DNA L. plantarum IS-10506 (Marker 1000 bp baris M, suhu $61.5^{\circ} \mathrm{C}$ baris $1,60.3^{\circ} \mathrm{C}$ baris $2,58.4^{\circ} \mathrm{C}$ baris $3,62^{\circ} \mathrm{C}$ baris 4)

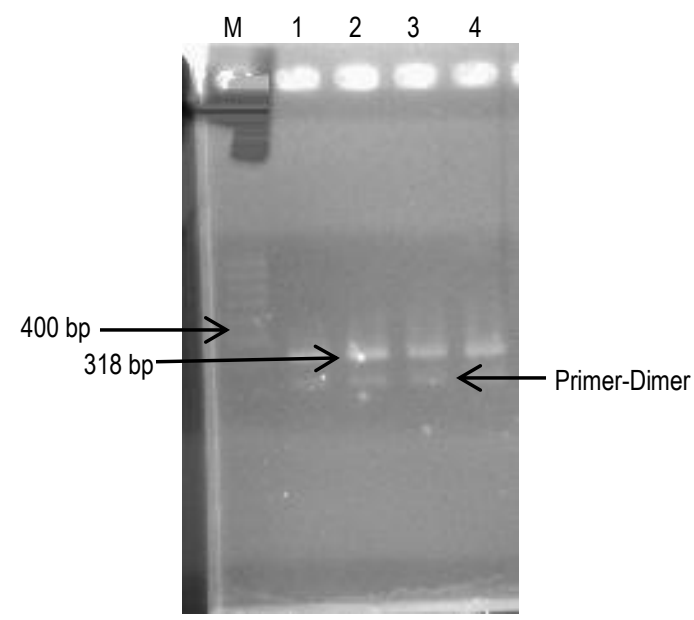

Gambar 2. Primer-dimer yang timbul pada saat optimasi suhu annealing primer dengan menggunakan DNA L. plantarum IS-10506 (Marker 1000 bp baris $\mathrm{M}$, suhu $52^{\circ} \mathrm{C}$ baris 1 , $52.8^{\circ} \mathrm{C}$ baris $2,54.1^{\circ} \mathrm{C}$ baris $3,55.9^{\circ} \mathrm{C}$ baris $458.4^{\circ} \mathrm{C}$ )

\section{Hasil pemeriksaan real time PCR pada sampel subjek}

Pada penelitian ini, sampel subjek yang diberi probiotik menunjukkan peningkatan jumlah Lactobacillus sp. dari minggu ke minggu, namun dalam analisis statistik tidak menunjukkan peningkatan yang signifikan. Perbandingan jumlah Lactobacillus sp pada kultur media MRS antara sampel partisipan yang diberi probiotik dan plasebo juga tidak signifikan, $p>0.05$.

Pemeriksaan dengan real time PCR dinyatakan positif bila hasil menunjukkan nilai $\mathrm{Ct}$ (cycle threshold) lebih kecil dari $\mathrm{Ct}$ kontrol negatif (jika kontrol negatif menunjukkan nilai $\mathrm{Ct}$ ) atau dinyatakan dalam melting curve dengan peak yang sama pada kontrol positif. Hasil qPCR terhadap partisipan yang diberikan probiotik Lactobacillus plantarum IS-10506 dicantumkan pada Tabel 1 sedangkan Hasil qPCR terhadap partisipan yang diberikan plasebo dicantumkan pada Tabel 2. 
Tabel 1. Hasil qPCR terhadap partisipan yang diberikan probiotik Lactobacillus plantarum IS-10506

\begin{tabular}{|c|c|c|c|c|}
\hline \multicolumn{5}{|l|}{ Probiotik } \\
\hline No Sampel & Minggu I & Minggu II & Minggu III & Minggu IV \\
\hline 1 & - & + & - & + \\
\hline 6 & - & + & + & + \\
\hline 9 & - & + & + & + \\
\hline 11 & + & + & + & + \\
\hline 19 & - & + & - & + \\
\hline 22 & + & + & + & + \\
\hline 29 & - & + & + & + \\
\hline B & - & - & - & - \\
\hline D & + & + & + & + \\
\hline $\mathrm{F}$ & - & + & + & + \\
\hline
\end{tabular}

Tabel 2. Hasil qPCR terhadap partisipan yang diberikan plasebo Placebo

\begin{tabular}{cccccc}
\hline No Sampel & Minggu I & Minggu II & Minggu III & Minggu IV \\
\hline 2 & - & - & - & - \\
4 & - & - & - & - \\
8 & + & + & - & - \\
15 & - & - & - & - \\
17 & + & - & - & - \\
18 & - & - & - & - \\
23 & - & - & - & - \\
24 & + & + & + & + \\
25 & - & + & - & + \\
26 & - & - & - & + \\
28 & - & + & + & - \\
$5 a$ & - & - & - & - \\
E & - & - & - & - \\
\hline
\end{tabular}

\section{Suhu annealing optimum}

Pemeriksaan Real Time PCR/qPCR pada penelitian in menggunakan primer yang digunakan pada penelitian Torriani et al. (2001) yaitu primer spesifik L. plantarum (planF 5' - CCG TTT ATG CGG AAC ACC TA - 3' Forward dan pREV 5' - TCG GGA TTA CCA AAC ATC AC - 3' Reverse). Menurut Torriani et al. (2001), primer spesifik untuk $L$. plantarum, planF terletak pada posisi 9 hingga 28 nukleotida dan pREV terletak pada nukleotida posisi 308-327. Dari perhitungan yang telah dilakukan untuk menentukan suhu annealing, diperoleh nilai $T_{m}$ $60^{\circ} \mathrm{C}$. $T_{m}$ (melting temperature) merupakan suatu suhu dimana kemungkinan $50 \%$ dari ikatan hidrogen terbentuk. Suhu annealing yang digunakan untuk suatu oligonukleotida $\left(T_{a}\right)$ umumnya $5^{\circ} \mathrm{C}$ di bawah atau di atas $T_{m}$ (Mackay, 2007).

$T_{m}$ (melting temperature) dari produk PCR tergantung komposisi buffer dan konsentrasi garam. Nilai $T_{m}$ yang didapat dengan menggunakan Fast Start SYBR Green Master reagents (Roche) kemungkinan akan berbeda dengan menggunakan reagen yang berbeda (Mackay, 2007). Pada kenyataannya suhu annealing yang diperoleh pada penelitian ini adalah adalah suhu $58.4^{\circ} \mathrm{C}$ atau suhu $58.5^{\circ} \mathrm{C}$. Seperti telah disebutkan di atas menggunakan metode PCR konvensional dengan primer yang sama, namun mendapatkan suhu annealing $55^{\circ} \mathrm{C}$. Hal ini kemungkinan disebabkan karena metode yang digunakan pada kedua penelitian berbeda.

Dalam mendapatkan suhu annealing diambil nilai $\mathrm{Ct}$ (Threshold cycle) yang terbaik dalam suhu gradien. Nilai $\mathrm{Ct}$ merupakan nilai yang menunjukkan adanya peningkatan deteksi oleh fluorescence. Konsentrasi primer mempengaruhi nilai $\mathrm{Ct}$, namun juga mempengaruhi spesifisitas reaksi. Konsentrasi primer yang tinggi dapat menyebabkan nilai $\mathrm{Ct}$ menjadi rendah, namun juga dapat menyebabkan atau meningkatkan produk non spesifik seperti primer-dimer.

Penggunaan melting curve untuk melihat adanya primer dimer, serta reaksi positif dapat dilakukan dengan cara mengatur suhu dari suhu terendah $\left(55^{\circ} \mathrm{C}\right)$ hingga tertinggi $95^{\circ} \mathrm{C}$. Pada suhu rendah semua produk PCR masih dalam keadaan untai ganda, sehingga Fast Start SYBR Green Master dapat berikatan dengan untai ganda DNA. Sebagai akibatnya fluorescence meningkat. Sedangkan pada suhu tinggi, produk PCR telah terdenaturasi dan mengakibatkan fluorescence menurun. Jika peak pada melting curve tidak sejajar dengan kontrol positif, maka akan terjadi primer-dimer (Mackay, 2007).

Penggunaan Fast Start SYBR Green Master pada penelitian ini terdapat kelebihan dan kekurangan sebagai berikut: 1) kelebihan: murah dan mudah digunakan, memiliki kemampuan lebih kuat daripada ethidium bromide, tidak menghalangi reaksi amplifikasi, dan tidak terpengaruh oleh mutasi dalam DNA target; 2) kekurangan: dapat menyebabkan positif palsu, memerlukan optimasi secara luas, sensitivitas tinggi namun kurang spesifik.

Hasil penenlitian ini memperlihatkan persamaan dalam terjadinya peningkatan jumlah $L$. plantarum di kultur media maupun dengan qPCR dari minggu ke minggu. Hasil kultur memperlihatkan jumlah yang lebih banyak. Hal ini disebabkan pada kultur bakteri yang terdeteksi bukan hanya L. plantarum melainkan Lactobacillus sp. Deteksi dengan qPCR menunjukkan nilai $\mathrm{Ct}$ yang cukup besar, yang artinya hanya sedikit jumlah DNA L. plantarum yang terdeteksi. Namun, pada sampel subjek yang diberi probiotik menunjukkan peningkatan yang signifikan pada jumlah DNA L. plantarum saat di deteksi dengan $q \mathrm{PCR}, p<0.05$.

\section{Batas deteksi}

Untuk pemeriksaan batas deteksi, bakteri ditumbuhkan dalam media MRS selama 14 hingga 16 jam pada suhu $37^{\circ} \mathrm{C}$ kemudian dimasukkan ke dalam PBS $1 \mathrm{x}$ dengan pengenceran berseri $\left(10^{-1}\right.$ hingga $\left.10^{-10}\right)$. Sebanyak $200 \mu \mathrm{L}$ volume dari masing-masing pengenceran diambil untuk kultur dan $200 \mu \mathrm{L}$ untuk qPCR. Hasil plating pada kultur didapat $4 \mathrm{CFU} / \mathrm{mL}$ pada pengenceran $10^{-7}$. Metode penelitian ini pernah dilakukan oleh Bujalance et al. (2006), namun terdapat perbedaan pada volume yang dipakai untuk pengenceran dan media pengencernya. Bujalance et al. (2006) memakai skim milk, dimana susu merupakan bahan pangan yang relatif sempurna dan merupakan media yang baik untuk pertumbuhan bakteri.

Pemeriksaan qPCR pada penelitian ini memiliki batas deteksi serial pengenceran lebih dari 10-10. Dari pemeriksaan batas deteksi menggunakan qPCR, dapat dikatakan bahwa qPCR lebih sensitif daripada pemeriksaan kultur media. Pada uji simulasi inhibitor dalam sampel feses memperlihatkan nilai $\mathrm{Ct}$ 
yang lebih besar, hal ini karena feses mengandung banyak komponen yang juga dapat menghambat pertumbuhan bakteri. Batas deteksi real time PCR dan kultur media MRS dicantumkan pada Tabel 3.

Tabel 3. Batas deteksi real time PCR dan kultur media MRS

\begin{tabular}{ccccc}
$\begin{array}{c}\text { Pengen- } \\
\text { ceran }\end{array}$ & $\begin{array}{c}\text { Ct qPCR } \\
\text { dari Kultur }\end{array}$ & $\begin{array}{c}\text { Ct qPCR dari } \\
\text { Simulasi } \\
\text { Adanya } \\
\text { Inhibitor } \\
\text { dalam Feses }\end{array}$ & $\begin{array}{c}\text { Jumlah } \\
\text { CFU/mL } \\
\text { dalam Kultur } \\
\text { (Pengencer } \\
\text { PBS 1x) }\end{array}$ & $\begin{array}{c}\text { Jumlah } \\
\text { CFU/mL } \\
\text { dalam Kultur } \\
\text { (Pengencer } \\
\text { Supernatant } \\
\text { Feses) }\end{array}$ \\
\hline $10^{-5}$ & 18.57 & 27.46 & 86 & 81 \\
$10^{-6}$ & 26.85 & 28.05 & 48 & 39 \\
$10^{-7}$ & 27.44 & 29.33 & 4 & 3 \\
$10^{-8}$ & 29.31 & 31.82 & - & - \\
$10^{-9}$ & 32.64 & 32.04 & - & - \\
$10^{-10}$ & 34.49 & 33.27 & - & - \\
\hline
\end{tabular}

\section{Spesifisitas primer}

Spesifisitas PCR sangat tergantung pada desain primer. Amplifikasi dan deteksi target dengan real time PCR dilakukan secara serempak. Pada uji spesifisitas primer terhadap bakteri uji seperti L. plantarum, E. coli, Pseudomonas aeuroginosa, Klebsiella pneumoniae, Bifidobacteria sp, Bacillus subtilis, Proteus mirabilis, Serratia marcescens, Enterobacter aerogenes, Salmonella Typhi, Shigella sp, dan Bacteroides fragilis dalam penelitian ini, primer spesifik hanya untuk $L$. plantarum. Pengujian spesifisitas primer spesifik $L$. plantarum dengan Lactobacillus sp lainnya sebagai bakteri uji telah dibuktikan oleh Torriani et al. (2001).

\section{Hasil pemeriksaan real time PCR pada sampel partisipan}

Dari hasil pemeriksaan qPCR terhadap sampel partisipan, pada minggu pertama atau sebelum diberikan perlakuan, beberapa sampel partisipan menunjukkan hasil positif, kemudian menjadi negatif di minggu-minggu berikutnya dan sebaliknya. Hal ini disebabkan oleh beberapa faktor seperti diet dan kontaminasi. Diet merupakan salah satu faktor penentu komposisi bakteri usus, disamping faktor dalam saluran pencernaan itu sendiri. Beberapa penelitian membuktikan populasi bakteri "jahat" dalam feses orang yang mengonsumsi diet makanan barat (tinggi lemak dan protein, rendah serat) lebih tinggi dibandingkan makanan Asia yang lebih banyak mengonsumsi sayuran. L. plantarum terdapat dalam berbagai makanan, sayuran dan buah, seperti asinan kubis, timun, buah markisa, sourdough. Kontaminasi dapat terjadi pada semua tahapan kerja mulai dari pengolahan spesimen, isolasi DNA, maupun pembuatan master mix PCR. Kontaminasi ini terjadi jika alur kerja dalam melakukan qPCR tidak dipatuhi. Pembuatan master mix, penambahan cetakan dan penambahan kontrol positif telah dikerjakan pada ruangan dan menggunakan alat-alat yang berbeda. Di samping itu, setiap pekerjaan dilakukan pada biosafety cabinet. Hal-hal tersebut dilaksanakan untuk menghindari kontaminasi. Pada penelitian ini selalu menggunakan kontrol positif $L$. plantarum, kontrol master mix dan kontrol isolasi untuk mengetahui adanya kontaminasi.
Pada penelitian ini tidak terjadi peningkatan jumlah Lactobacillus sp secara signifikan dalam sampel subjek yang mengonsumsi probiotik. Peningkatan jumlah Lactobacillus sp antara subjek yang diberi probiotik atau plasebo juga tidak menunjukkan perbedaan yang bermakna. Hal yang mempengaruhi hasil pemeriksaan kultur antara lain media pertumbuhan dan kepatuhan subjek.

Dalam media MRS agar, dengan penambahan indikator brom cresol purple, Lactobacillus sp membentuk koloni berukuran 2-3 mm, cembung, berwarna kuning setelah 48 jam diinkubasi pada suhu $37^{\circ} \mathrm{C}$. Warna kuning disebabkan karena kemampuan Lactobacillus sp memproduksi asam. Pada penelitian ini media MRS yang digunakan hanya untuk melihat pertumbuhan Lactobacillus sp secara keseluruhan pada sampel feses baik dari partisipan yang diberikan probiotik maupun plasebo. Jumlah Lactobacillus sp dalam feses setiap subjek bervariasi, kisaran jumlah Lactobacillus $\mathrm{sp}$ bervariasi untuk setiap individu mulai dari 5.1 hingga 8.3 log CFU/g. Saxelin et al. (2010) memperlihatkan bahwa komposisi dari indigenous microflora bervariasi dari suatu periode hingga beberapa bulan.

Untuk dapat memberikan efek probiotik, Lactobacillus sp harus dapat menempel dan mengkolonisasi permukaan mukosa lebih lama. Pelekatan pada mukosa memperpanjang waktu probiotik untuk berperan dalam sistem imun saluran pencernaan, kemampuan melekat pada permukaan usus berhubungan dengan efektivitas strain probiotik dalam memberikan manfaat kesehatan. Proses terjadinya pelepasan dari penempelan bakteri dipermukaan mukosa dideskripsikan dengan hubungan sebagai berikut: washout rate $=$ Specific growth rate = dilution rate. Dilution rate yang berlaku disini merupakan keseimbangan antara dilutionof intestinal water yang menumpuk pada permukaan mukosa oleh air dan makanan yang dikonsumsi serta kemampuan bakteri untuk dapat bertahan dari pelepasan di permukaan mukosa.

Untuk dapat bertahan di permukaan mukosa, bakteri harus dapat tumbuh dan membelah diri dengan rata-rata Specific growth rate yang sama dengan dilution rate yang berlaku. Hal ini menegaskan bahwa di samping berkompetisi secara langsung dengan bakteri lain untuk melekat, laju pertumbuhan menentukan kemampuan probiotik untuk dapat berkolonisasi dan menetap pada permukaan usus. Konsentrasi yang tinggi dari probiotik yang dikonsumsi meningkatkan kemampuan bakteri probiotik untuk menempel pada permukaan usus (Lee et al. 2004). Namun, bakteri probiotik tidak berkolonisasi secara tetap, pemberian probiotik dapat dideteksi pada feses selama beberapa hari atau minggu setelah cessation dan akan berkurang secara bertahap, artinya hanya terjadi kolonisasi sementara (Surono, 2004).

Kepatuhan partisipan dalam penelitian sangatlah penting. Kekurangpatuhan partisipan dalam meminum kapsul yang diberikan. Terjadinya tukar-menukar kapsul antara partisipan yang diberikan probiotik dan plasebo, cara pengambilan sampel, penanganan selama perjalanan ke laboratorium mempengaruhi hasil pemeriksaan baik kultur maupun qPCR. Pada hasil pemeriksaan qPCR nilai $\mathrm{Ct}$ masih jauh dari nilai $\mathrm{Ct}$ pada kontrol positif (Ct kontrol positif berkisar antara 25 sampai 28). Walaupun dinyatakan positif namun nilai $\mathrm{Ct}$ yang jauh lebih 
besar daripada nilai $\mathrm{Ct}$ kontrol positif memperlihatkan jumlah DNA sampel yang sangat sedikit.

Penelitian ini memiliki beberapa kelemahan seperti tidak dipakainya media pertumbuhan spesifik untuk kultur $L$. plantarum, kekurang pahaman subjek dalam hal pemahaman akan pentingnya penelitian, pemakaian Fast Start SYBR Green Master memiliki sensitivitas yang tinggi namun spesifisitasnya rendah. Untuk mengatasi kelemahan ini dapat dilakukan penelitian lanjutan dengan memakai media pertumbuhan yang spesifik dan penggunaan probe untuk PCR.

\section{KESIMPULAN}

Penelitian terhadap viabilitas bakteri Lactobacillus sp pada individu dewasa sehat yang diberi perlakuan terbukti tidak berbeda nyata dalam peningkatan jumlah koloni bakteri Lactobacillus sp dibanding subjek yang diberikan plasebo pada pemeriksaan dengan kultur media pertumbuhan $(p>0.05)$. Data hasil pemeriksaan qPCR menunjukkan keberadaan bakteri $L$. plantarum dari sampel subjek pada kelompok perlakuan terbukti terjadi peningkatan (nilai $\mathrm{Ct}$ ) nyata dibanding subjek plasebo $(p<0.05)$. Pada pemeriksaan $\mathrm{qPCR}$, keberadaan bakteri $L$. plantarum dinyatakan dalam nilai $\mathrm{Ct}$ dan peak yang sesuai dengan kontrol positif pada grafik melting curve. Spesifisitas primer dibuktikan dengan menguji primer dengan berbagai bakteri uji seperti Escherichia coli, Pseudomonas aeuroginosa, Klebsiella pneumonia, Bifidobacteria sp, Bacillus subtilis, Proteus mirabilis, Serratia marcescens, Enterobacter aerogenes, Salmonella Typhi, Shigella sp, dan Bacteroides fragilis dan primer dinyatakan spesifik untuk $L$. plantarum IS10506. Batas deteksi menggunakan qPCR lebih sensitif daripada pemeriksaan kultur media.

Kegiatan penelitian lanjutan yang perlu dilakukan yaitu yang berkenaan dengan keberadaan bakteri asam laktat (BAL) sebagai probiotik dengan menggunakan media pertumbuhan yang spesifik seperti LPSM (L. plantarum Selective Media) dan pemakaian probe untuk real time PCR serta stabilitas bakteri dalam kemasan. Selain itu, bahan penelitian dapat menggunakan minuman atau berupa yogurt dibandingkan kapsul.

\section{UCAPAN TERIMA KASIH}

Penulis mengucapkan terima kasih kepada SEAMEO TROPMED, Regional Center for Community Nutrition Universitas Indonesia, melalui nomor kontrak: RUUI No: 747Q/DRPM-UI/A/N1.4/2009 atas biaya penelitian yang diberikan.

\section{DAFTAR PUSTAKA}

Bixquert JM. 2009. Treatment of irritable bowel syndrome with probiotics: an etiopathogenic approach at last. Rev Esp Enferm Dig 101: 553-564.

Bujalance C, Valera MJ. 2006. A selective differential medium for Lactobacillus plantarum. J Microbial mehod 66: 572-575. DOI: 10.1016/j.mimet.2006.02.005.

Collado MC, Surono IS, Jussi Meriluoto, Seppo Salminen. 2007a. Indigenous dadih lactic acid bacteria: Cell-surface properties and interactions with pathogens, J Food Sci 72: 89-93. DOI: 10.1111/j.1750-3841.2007.00294.x.

Collado MC, Surono IS. Jussi M, Seppo S. 2007b. Potential probiotic characteristics of Lactobacillus and Enterococcus strains isolated from traditional dadih fermented milk against pathogen intestinal colonization. J Food Prot 70: 700-705.

de Vrese M, Kristen H, Rautenberg P, Laue C, Schrezenmeir J. 2011. Probiotic Lactobacilli and Bifidobacteria in a fermented milk product with added fruit preparation reduce antibiotic associated diarrhea and helicobacter pylori activity. J Dairy Res 78: 396-403. DOI: 10.1017/S002202991100063X.

Lee YK, Ho PS. Low CS, Arvilommi H, Salminen. 2004. Lactobacillus is hindered by the slow rate of cell division in the mouse gut. J Appl Environ Microb 70: 670-674. DOI: 10.1128/AEM.70.2.670-674.2004.

Mackay IM. 2007. Real Time PCR in Microbiology from Diagnosis to Characterisation. Caister Academic Press. Norfolk.

Nissen L, Chingwaru W, Sgorbati B. 2009. Gut health promoting activity of new putative probiotic/protective Lactobacillus spp. Strains: A functional study in the small intestinal cell model. J Food Microbiol 135: 288-94. DOI: 10.1016/j. ijfoodmicro.2009.08.027.

Surono IS. 2003. In vitro probiotic properties of indigenous dadih lactic acid bacteria. J Asian Anim 16: 726-731.

Surono IS. 2004. Probiotik Susu Fermentasi dan Kesehatan. 225-228. YAPMMI, Jakarta.

Surono IS. 2009. In vivo antimutagenicity of dadih probiotic bacteria toward Trp-P1. J Anim Sci 22: 119-123.

Torriani S, Felis GE. 2001. Differntiation of Lactobacillus plantarum, $L$. pentosus, and $L$. paraplantarum by rec A gene sequence analisys and Multiplex assay with rec $A$ gen derived primers. J Appl Environ Microb 3450-3454. DOI: 10.1128/AEM.67.8.3450-3454.2001.

Wells JM. 2011. Immunomodulatory mechanisms of Lactobacilli. J Microb Cell Fact 10: S17. DOI: 10.1186/1475-2859-10-S1S17. 